\title{
The New Trend of American Literature Research
}

\author{
Dan Tao* \\ Zhaotong University, Zhaotong 657000, China \\ *Corresponding Author email: 463131871@qq.com
}

Keywords: American literature; dictionary; new trend

\begin{abstract}
Since the establishment of the earliest modern American Literature Research Institute in 1979, the American Institute of modern literature has been established. The study of Chinese American literature has gone through more than 30 years and has made considerable progress. The study of American literature is becoming more and more internationalized, and the influence of foreign born and American based researchers abroad is also growing. This paper attempts to explain this phenomenon and its evolution, and selectively analyzes the new comparative methods in the study of American literature. The dictionary of American literature, edited by Yu Jianhua, is the first Chinese original dictionary of American literature. It is not only an excellent information query tool, but also a faithful embodiment of the author's academic ideas. It has expanded the research scope of American literature. It highlights the cultural perspective of literary research, pays attention to the retrospective inheritance of literary research, and emphasizes the subject consciousness of literary research. While it is convenient for readers to read, it will exert its academic influence and normative function in a subtle way.
\end{abstract}

\section{Introduction}

In September 2015, the dictionary of American Literature (short Dictionary), edited by Yu Jianhua, was published by the commercial press [1]. As the first Chinese original dictionary of American literature, its publication is of great significance. To write such a dictionary, first of all, the writer needs to have a solid academic background [2]. Professor Yu Jianhua, a chief editor, has been engaged in the study of American literature for decades [3]. He is a famous scholar in China and has made great achievements in the field of American literature. The participants are all scholars in the field of American literature research [4]. They all have doctoral degrees and have certain attainments in their respective research fields. The current study of American literature is in a period of both exciting and perplexing, and the momentum of the past twenty years is more centrifugal than centripetal [5]. In recent years, the literary critics at home and abroad have expanded some important theoretical and aesthetic research projects in 1980s, forming some exciting new directions [6]. On the one hand, some traditional themes and research areas are revitalized; on the other hand, many new theories, ideas and historical contexts have been established. As a result, while the scope of the text is expanding rapidly, writers and works in the old text system are also given new explanations.

\section{Expanding the Research Territory of American Literature}

Chinese American literature often refers to the works of classical writers from the perspective of influence and research. Chinese readers, who are familiar with and delight in talking with Chinese scholars, are always the most classical and important writers. The compilation of the history of American literature is a good example: from the authoritative single language mode in the past to the present polyphony system. No longer attempts to make a summary of the full picture of American Literature in a large historical perspective, but a special and phased presentation of the characteristics of American literature, forming the complementarity and coexistence of multiple texts. For readers who are not for the purpose of research, the words of popular fiction in the dictionary provide them 
with the opportunity to check information, understand systematically and extend reading. To a certain extent, it enables readers to read in and read out and improve their understanding level. American Literature in China is not just a matter of academia, but of all scholars. The dictionary gives full consideration to the reality of Chinese literature in the United States and pays more attention to Chinese writers and scholars. This kind of attention is mainly embodied in two aspects. On the one hand, the overall introduction to the writer is more detailed, especially for his literary achievements and literary influence. On the other hand, there are more single entries to introduce their representative works. The dictionary is a reflection of the importance of Chinese readers and scholars, as shown in Table 1.

Table. 1 The dictionary is the main embodiment of Chinese readers and scholars

\begin{tabular}{cc}
\hline Pay attention to the main embodiment \\
\hline Chinese readers & $\begin{array}{c}\text { The introduction to the writer is more detailed, especially } \\
\text { for his literary achievements and literary influence. } \\
\text { The representative introduction of more single entries }\end{array}$ \\
\hline
\end{tabular}

In today's research field of American literature, we can find that from contemporary American writers to American writers in the last century. From American writers who are more concerned to American literary writers whose works are relatively unpopular. His works are in the research scope of today's Gome American literature. As shown in Figure 1.

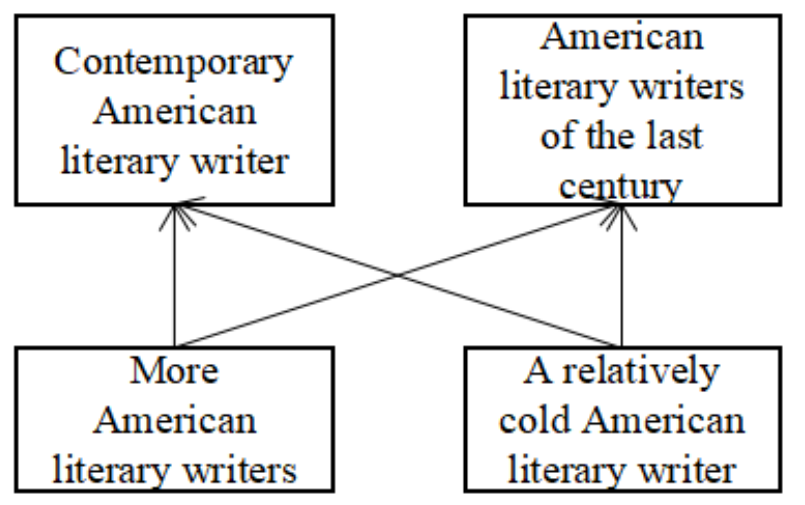

Figure. 1 The framework of American literature research

The dictionary also incorporated American popular novels. The entries on popular novels are written by Huang Lushan, the author of the history of American popular fiction and professor of Shanghai Univer. In this way, there are at least two meanings. First, promote the research of American popular fiction. Popular fiction is an indispensable part of American literature. Both its novels and the adaptation of films and TV plays have an extraordinary influence. Secondly, it provides convenience for Chinese readers. American Literature in China is not just a matter of academia, but of all scholars. American popular fiction and its adaptation of film and television works have a large audience in China. The first history of American literature is written by an expert on American Literature in the Chinese Academy of social sciences. Due to the influence of the political environment at that time and the lack of literature, the literary history, on the basis of the original version of the original edition, has joined a lot of views with strong cultural autocratic tendencies. But American literature, after all, has many writers, who have a certain position in the history of American literature but have no interest in China. It also occupies a certain length in the dictionary, which ensures the search rate of the dictionary and meets the needs of different readers, thus providing the user with a full picture of American literature at the same time. Although these views are unbiased, it is still of great value to look at the history of literature as a whole and to outline the development of American literature and play a leading role in the development of American literature. Considering the power of popular literature and the tendency of cultural research in literature, American popular novels are included in the dictionary. Expanding the scope of Chinese literature in the United States will help attract Chinese 
scholars' attention to this field and promote relevant research. The meaning of American popular novels in the dictionary is shown in Table 2.

Table. 2 The significance of the American popular novels in the dictionary of the Great Dictionary

\begin{tabular}{cc}
\hline & Significance \\
\hline First & Research on American popular fiction \\
Second & Provide convenience for Chinese readers \\
\hline
\end{tabular}

\section{The Retroactive Inheritance of Literature Research}

Apart from the author's works, the dictionary also includes literary critics, literary theorists and literary historians. This arrangement has greatly facilitated the current literary study, because our research is not only based on the works of the writers, but also on the achievements of previous studies. In recent years, a number of thematic and phased treatises on American literature have also appeared. The study of American literature is not only increasing in depth, but also expanding in breadth. The above three kinds of people often play a foundation, leading or even normative role in literary research. Descendants' research is on their shoulders and their path. The dictionary can not only help scholars understand the information of specific scholars, but also find the most important critics and theorists of American literature from various angles, so as to carry out targeted studies and studies. Therefore, the translation of American literary works in foreign literature in twenty-first Century is as high as $78 \%$, while Chinese commentaries only account for $19 \%$. In the translation works, the short stories and poems are the main ones (see Figure 2).

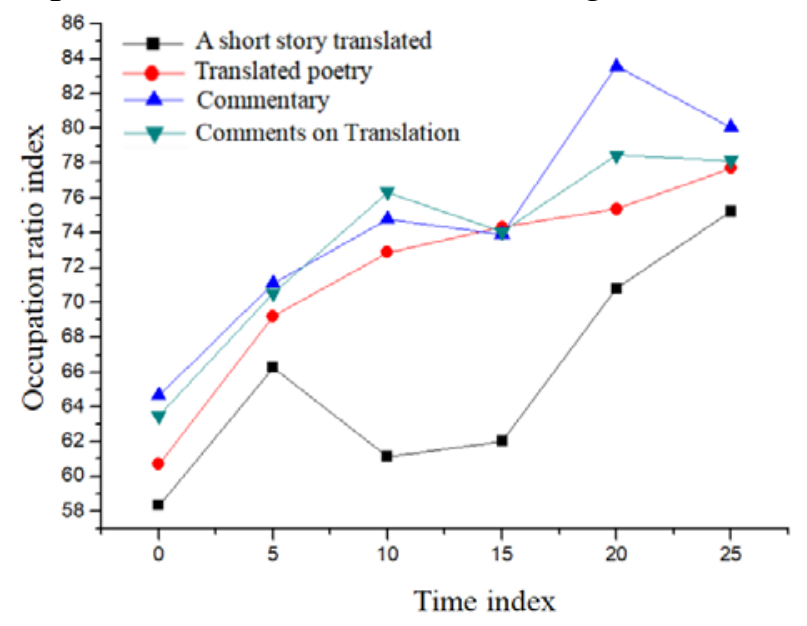

Figure. 2 The proportion of different texts in American Literature in the twenty-first Century

From the distribution of writers, it can be seen that most writers have only once appeared, but there are seven writers - Updike, Tang Tingting, Morrison, Hemingway, Bellow, Pound and about Heller at least in the five period of "foreign literature". In addition, eight writers, including Oates, Betty, Carver, Malamud, Mason, Updike, Sandberg and Hemingway, also appeared in more than four or five publications (see Table 3 and table 4).

Table. 3 Seven writers who are most subject to Chinese scholars' attention

\begin{tabular}{cc}
\hline $\begin{array}{c}\text { Scholar's attention to } \\
\text { index }\end{array}$ & Writer \\
\hline 9 & Updike \\
8 & Maxine Hong Kingston \\
8 & Morrison \\
9 & Hemingway \\
7 & Saul Bellow \\
7 & Pound \\
8 & About Heller \\
\hline
\end{tabular}


Table. 4 Eight writers of the most translators' attention

\begin{tabular}{cc}
\hline $\begin{array}{c}\text { Translator's attention } \\
\text { to the index }\end{array}$ & Writer \\
\hline 7 & Oates \\
5 & Betty \\
5 & raymond carver \\
5 & Malamud \\
5 & Mason \\
6 & Updike \\
8 & Sandberg \\
8 & Hemingway \\
\hline
\end{tabular}

The great contribution of the dictionary is a guide to the criticism of each writer's entries, including the representative works of foreign countries and the classic domestic translation, most of the relevant monographs, doctoral papers and major academic journals. The study of American Literature in the West has a long history, and since the beginning of the late Qing Dynasty and the beginning of the Republic of China, the translation and study of American literature have also been produced. How to inherit and carry forward the existing achievements and bring forth new ideas is a problem faced by every researcher. Although web search is developed now, it is not easy to get comprehensive information. Especially since the reform and opening up and the expansion of the school enrollment, the research results of American literature have springing up. Massive collection is rare; screening and screening are even more valuable. The critical guide in the dictionary carries out the principle of "comprehensive" and "important", which is of great reference value. It is particularly important for scholars to study, select research objects and make research plans. Not only can we take fewer detours and avoid duplication, but we can also collect information on the most important research items and start work at a higher starting point. In the past, there were not many opportunities for domestic contact with American literature. On the one hand, they were influenced by the mainstream ideology. On the other hand, due to the limitation of cultural transmission ability, the scope of domestic research on American literature is very small at that time. As shown in Table 5.

Table. 5 Two aspects of the impact of domestic literature on American Literature

\begin{tabular}{cc} 
First & $\begin{array}{c}\text { Main impact } \\
\text { Influenced by the mainstream } \\
\text { thought }\end{array}$ \\
Second & $\begin{array}{c}\text { The limitations of cultural } \\
\text { communication ability }\end{array}$ \\
\hline
\end{tabular}

\section{Conclusion}

The academic value of the dictionary is reflected not only in the macro design but also in the microscopic operation. The word "one word" has been repeatedly checked and checked, and has a very high reference value, especially the translation of the name of the writer's works, which provides a certain standard for the academic community. Worried that literary scholars will isolate themselves from science, commerce and the market, they are too narrowly focused on individual details. He proposed that literary research should embrace the history of literature and embrace the future of technology, and train a generation of critics. So that it can convey the meaning and mystery of literature to the society that cares about the material world and technology is more interested in thinking, life and imagination. Therefore, only a more in-depth study of the origin and pluralism of American literature can make it possible to better understand the connotation of American literature and grasp its development. The translation of literary names in a variety of domestic settings has set obstacles to data retrieval and literary understanding. The great dictionary must play an important role 
in standardizing the pursuit of faithful translations, so as to facilitate readers and promote the study of American Literature in China.

\section{References}

[1] Oguri K. Pronouncing Dictionaries of American English [J]. The humanities. Section II, Language and literature; Journal of the Yokohama National University, 1955, 4:18-26.

[2] Okuda N. Stress Patterns of Compounds and Idiomatic Phrases in English Dictionaries [J]. Japan Womens University Studies in English \& American Literature, 1981, 16:1-17.

[3] Duckett B. Dictionary of American Literary Characters (2nd edition) [J]. Reference Reviews, 2002, 16(7):20-21.

[4] Compliment A. The Age of Maturity, 1929-1941 (Concise Dictionary of American Literary Biography Series) by Matthew J. Bruccoli; Richard Layman; C. E. Frazer Clark [J]. American Studies International, 1990(2Special):115-116.

[5] Karasik O, Pomortseva N, Bobyreva N. EXPLORING ENGLISH AND AMERICAN LITERATURE IN LINGUISTIC ACADEMIC COURSES[C]// International Technology, Education and Development Conference. 2016:7444-7450.

[6] Smith J D. Dictionary of Literary Biography, Volume Forty-three. American Newspaper Journalists, 1690-1872, and: Dictionary of Literary Biography, Volume Forty-seven. American Historians, 1866-1912 (review)[J]. Civil War History, 1991, 37(2):158-161. 